\title{
Komunikasi Pemasaran Brand Lokal Kepada Masyarakat Indonesia (Studi Terhadap Beras Sikoki)
}

\author{
Evin Cornellin, Sinta Paramita \\ epin.cornellin@gmail.com, sitas@untar.ac.id
}

Fakultas Ilmu Komunikasi, Universitas Tarumanagara

\begin{abstract}
Brand can create interactive communication with consumers. The stronger a brand, the stronger the interaction with consumers. To introduce the brand to the public, not to mention local brands, especially the Sikoki rice brand. CV. Padi Mas (Sikoki rice producer) has always made a breakthrough related to popularizing Sikoki rice, namely by using strategies, including marketing communication strategies. Marketing communication is a marketing activity that seeks to disseminate information, persuade, remind target markets so that their products are willing to accept, buy and be loyal to the products offered by the company concerned. The concept of marketing communication strategy is to determine segmentation, target market, positioning and differentiation. This is so that in promoting their products can be carried out effectively and efficiently. In implementing marketing communication strategies, companies also use a promotional mix that includes sales promotion, direct marketing, advertising promotion and internet marketing.
\end{abstract}

Keywords: Marketing Communication, Local Brand, Sikoki Rice.

\begin{abstract}
Abstrak
Brand mampu menciptakan komunikasi interaktif dengan konsumen. Semakin kuat suatu brand, semakin kuat pula interaksinya dengan konsumen. Guna memperkenalkan brand ke masyarakat, tak terkecuali brand lokal, khususnya brand beras Sikoki. CV. Padi Mas (produsen beras Sikoki) selalu membuat terobosan terkait dengan mempopulerkan beras Sikoki yaitu dengan menggunakan strategi, diantaranya adalah strategi komunikasi pemasaran. Komunikasi pemasaran merupakan sebuah aktivitas pemasaran yang berusaha menyebarkan informasi, membujuk, mengingatkan pasar sasaran agar produknya agar bersedia menerima, membeli dan loyal terhadap produk yang ditawarkan perusahaan yang bersangkutan. Konsep strategi komunikasi pemasaran adalah dengan menentukan segmentasi, target pasar, positioning dan diferensiasi. Hal ini dimaksudkan agar dalam mempromosikan produknya dapat dilaksanakan secara efektif dan efisien. Dalam melaksanakan strategi komunikasi pemasaran, perusahaan juga menggunakan bauran promosi yang meliputi promosi penjualan, pemasaran langsung, promosi iklan dan internet marketing.
\end{abstract}

Kata Kunci : Komunikasi Pemasaran, Brand Lokal, Beras Sikoki.

\section{Pendahuluan}

Brand merupakan suatu hal yang penting bagi setiap perusahaan. Brand dapat menjadi suatu penghubung antara perusahaan dan konsumennya. Reputasi brand yang baik di mata konsumen akan berpengaruh terhadap keputusan pembelian yang dilakukan oleh konsumen untuk menggunakan produk dari perusahaan tersebut. Brand juga sebagai perantara yang menjembatani harapan konsumen pada saat produsen menjanjikan suatu kelebihan dari produknya kepada konsumen. Brand 
bermanfaat bagi pembeli, perantara, produsen maupun publik lain. Menurut Keller dalam Tjiptono (2005) brand bermanfaat bagi produsen dan konsumen.

Pada aspek lain, strategi penempatan brand adalah salah satu strategi dalam komunikasi pemasaran yang merupakan salah satu strategi perusahaan untuk mengomunikasikan produknya secara efektif kepada pelanggannya. Hal ini bertujuan untuk menciptakan hubungan brand yang kuat dan bersifat jangka panjang melalui elemen komunikasi yang ada pada level manajemen pemasaran yang pada akhirnya akan dapat menciptakan penjualan dan keuntungan bagi perusahaan. (Priansa, 2017)

Komunikasi pemasaran memiliki peran kunci dalam membentuk citra brand dan meningkatkan penjualan sebuah brand. Brand-brand terbaik dapat memberikan jaminan kualitas bagi konsumennya. Brand juga merupakan sebuah janji perusahaan untuk secara konsisten memberikan gambaran, semangat, dan pelayanaan pada konsumen. Hal yang harus diperhatikan para pemasar adalah bagaimana mengkomunikasikan merek ini supaya reputasi atau citra perusahaan dapat dibangun dengan merek yang kuat. Brand juga menjadi alat komunikasi antara perusahaan dengan konsumennya. Melalui brand, maka konsumen mengungkapkan kesadarannya, identitasnya dan pilihannya. Brand kemudian muncul sebagai objek budaya dan ideologi konsumennya. Ketatnya situasi persaingan usaha, perkembangan teknologi dan perubahan perilaku konsumen membuat pemasar harus menerapkan komunikasi pemasaran sehingga mampu membentuk atau melakukan pertukaran informasi dengan satu sama lainnya, yang pada gilirannya akan tiba saling pengertian yang mendalam. (Cangara, 2005) Ini artinya bahwa brand mampu menciptakan komunikasi interaktif dengan konsumen. Semakin kuat suatu brand, semakin kuat pula interaksinya dengan konsumen. Terkait dengan terjalinnya interaksi tersebut, tentunya dalam hal ini pemasar melakukan banyak hal guna memperkenalkan brand ke masyarakat, tak terkecuali brand lokal, khususnya brand beras.

Saat ini brand beras yang beredar di pasaran jumlahnya sangat banyak dan semuanya menawarkan beras-beras berkualitas. Tentunya para pelaku bisnis di bidang beras melakukan banyak terobosan dengan cara mempopulerkan brand lokal melalui promosi dan pemasaran guna bagaimana produk besar yang dihasilkan dikenal masyarakat secara luas. Pada penelitian ini, penulis membatasi brand beras lokal merek "Sikoki". Beras Sikoki merupakan beras putih berjenis ramos yang diolah dengan teknologi terbaru sehingga menghasilkan beras dengan kualitas terbaik. Beras berkualitas Sikoki dapat ditemukan di berbagai tempat seperti pasar swalayan dan lain-lain. Melayani berbagai jumlah permintaan dengan menggunakan jasa pribadi sehingga kualitas beras yang di antar tetap terjaga mutu dan kualitasnya. Adapun slogan Beras Sikoki adalah Beras Sikoki "Pas Dihati".

Mempopulerkan Beras Sikoki tentunya dengan menggunakan strategi, diantaranya adalah strategi komunikasi pemasaran. Komunikasi pemasaran merupakan sebuah aktivitas pemasaran yang berusaha menyebarkan informasi, membujuk, mengingatkan pasar sasaran agar produknya agar bersedia menerima, membeli dan loyal terhadap produk yang ditawarkan perusahaan yang bersangkutan. (Tjiptono, 2001)

Komunikasi pemasaran atas suatu brand dalam sebuah perusahaan akan dapat membantu menginformasikan pada publik dengan penyediaan informasi akurat yang mudah dimengerti, sehingga menghasilkan pengetahuan dan pengertian terhadap organisasi, perusahaan atau produk. Dengan demikian strategi komunikasi pemasaran memiliki peran yang sangat penting bagi perusahaan untuk 
Evin Cornellin, Sinta Paramita: Komunikasi Pemasaran Brand Lokal Kepada Masyarakat Indonesia (Studi Terhadap Beras Sikoki)

mengkomunikasikan brand beras yang dipasarkan, sehingga dapat meningkatkan penjualan dan produk semakin dikenal oleh masyarakat.

\section{Landasan Teori}

\section{Komunikasi Pemasaran}

Menurut Kotler (2008:8) komunikasi pemasaran adalah suatu scape yang menantang dan informasi internal (perusahaan) sampai dengan sistem pengambilan keputusan konsumen. Termasuk di dalamnya pesan dan citra produk yang dipresentasikan oleh perusahaan kepada konsumen potensil maupun stakeholders lainnya.

Selanjutnya menurut Fill (2009:13) definisi dasar komunikasi pemasaran adalah proses manajemen di mana organisasi masuk untuk melakukan komunikasi kepada berbagai ragam masyarakat. Komunikasi pemasaran merupakan promosi dari organisasi mengenai apa yang ditawarkan dan memberi makna tentang tindakan dalam proses pemasaran yang berdampak pada benak konsumen.

Di sisi lain, selain komunikasi pemasaran, marketer juga menggunakan komunikasi pemasaran terpadu untuk memasarkan produknya ke pelanggan. Menurut Schultz dalam Alifahmi (2005:14), komunikasi pemasaran terpadu atau integrated marketing communication (IMC) merupakan komunikasi antara pemasar dan pelanggan, berupa upaya untuk berbicara dengan orang-orang yang membeli maupun tidak membeli produk. Ini berarti mengundang respon, bukan cuma upaya monolog, tetapi juga tanggung jawab atas hasilnya. Sedangkan menurut DeLozier (1966) dalam Alifahmi (2005:14), komunikasi pemasaran adalah dialog yang berkesinambungan antara para pembeli dan penjual dalam suatu arena pasar. Nickels (2004) menyebut komunikasi pemasaran sebagai pertukaran informasi dua arah dan persuasi yang memungkinkan proses pemasaran berfungsi lebih efektif dan efisien.

\section{Merek (Brand)}

Menurut Keller (2003), merek (brand) adalah produk yang mampu memberikan dimensi tambah dan yang secara unik membedakannya dari produkproduk lain yang dirancang untuk memuaskan kebutuhan serupa. Perbedaan tersebut bisa bersifat rasional dan tangiable (terkait dengan kinerja produk dari merek bersangkutan) maupun simbolik, emosional dan tangiable (berkenaan dengan representasi merek). Tjiptono (2005), dengan kata lain, brand mencerminkan keseluruhan keseluruhan persepsi dan perasaan konsumen mengenai atribut dan kinerja produk, nama brand dan maknanya, dan perusahaan yang diasosiasikan dengan brand yang bersangkutan.

Pengertian brand menurut David A. Aaker (Ruslan, 2010) adalah nama dan simbol yang bersifat membedakan (seperti sebuah logo, cap, atau kemasan) dengan maksud, mengidentifikasikan barang dan jasa dari seorang penjual.

Brand adalah suatu nama, istilah, tanda, simbol, desain, atau gabungan dari elemen-elemen tersebut yang tujuannya untuk mengidentifikasi suatu produk atau jasa dengan kompetitornya.

A brand is a "name, term, sign, symbol, or design, or a combination of them, intended to identify the goods and services of one seller or group of sellers and to differentiate them from those of competition (Keller, 2008). 
Branding juga merupakan keseluruhan pengalaman dan persepsi konsumen/prospek pada brand yang dapat kita pengaruhi melalui marketing (Scot dan Alison, 2019). Brand yang kuat pada sebuah produk atau layanan dapat meningkatkan pertumbuhan penjualan, sedangkan branding sebuah perusahaan dimaksudkan untuk menarik dan mempertahankan karyawan yang terbaik (Scot dan Alison, 2019).

\section{Strategi Pemasaran}

Strategi pemasaran pada dasarnya adalah rencana yang menyeluruh, terpadau dan menyatu dibidang pemasaran yang memberikan panduan tentang kegiatan yang akan dijalankan untuk dapat tercapainya tujuan pemasaran dari suatu perusahaan. Dengan kata lain strategi pemasaran adalah serangkaian tujuan atau sasaran, kebijakan dan aturan yang memberi arah kepada usaha-usaha pemasaran perusahaan dari waktu-kewaktu, pada masing-masing tingkatan dan acuan serta alokasinya, terutama sebagai tanggapan perusahaan dalam menghadapi lingkungan dan keadaan persaingan yang selalu berubah. (Assauri, 2002)

Cravens dan Piercy (2013) menyatakan bahwa strategi pemasaran merupakan proses market driven dari pengembangan strategi yang mempertimbangkan perubahan lingkungan dan kebutuhan untuk menawarkan superior customer value. Focus strategi pemasaran adalah kinerja organisasi. Dalam hal ini strategi pemasaran menghubungkan organisasi dengan lingkungan serta memandang pemasaran sebagai suatu fungsi yang memiliki tanggungjawab melebihi fungsi lain dalam keseluruhan aktivitas bisnis. Proses strategi pemasaran meliputi penyusunan strategi pemasaran, pengembangan program pemerintah, serta implementasi dan pengendalian strategi pemasaran.

Strategi pemasaran terfokus pada mencari dan memberi kepada pelanggan superior, serta memiliki nilai yang berbeda untuk mengembangkan bisnis. Strategi pemasaran juga bertujuan untuk meningkatkan penjualan, karena penjulan merupakan ujung tombak dari strategi yang diterapkan disebuah perusahaan. (Kheng-Hor, 2005)

\section{Metode Penelitian}

Penelitian ini menggunakan metode kualitatif dengan sifat deskriptif, yang bermaksud untuk menggambarkan bagaimana temuan hasil penelitian dalam menjawab rumusan masalah yang telah dikemukakan pada bagian sebelumnya. Data dalam penelitian ini diperoleh melalui wawancara mendalam dengan narasumber, observasi, dan juga studi pustaka. Subjek dalam penelitian ini adalah informan kunci, yaitu Bapak Steven selaku Owner CV. Padi Mas (produsen Beras Sikoki), dan informan lain yaitu Bapak Widagdo Sutiman selaku penjual Beras Sikoki dan Sdr. Herman Sutady selaku konsumen dari beras Sikoki. Objek dalam penelitian ini adalah "brand beras Sikoki". Peneliti melakukan observasi pada brand beras Sikoki. Beras Sikoki merupakan beras putih berjenis ramos yang diolah dengan teknologi terbaru sehingga menghasilkan beras dengan kualitas terbaik. Data penelitian yang telah didapatkan, kemudian diolah dan dianalisis. Proses analisis data dimulai dengan menelaah seluruh data yang tersedia dari berbagai sumber, yaitu wawancara, pengamatan yang sudah dituliskan dalam catatan lapangan, dokumentasi resmi, gambar. Untuk mendapatkan data yang lengkap dan dapat dipertanggungjawabkan, 
Evin Cornellin, Sinta Paramita: Komunikasi Pemasaran Brand Lokal Kepada Masyarakat Indonesia (Studi Terhadap Beras Sikoki)

penelitian menggunakan sebagai berikut: wawancara, pengamatan, data dari perusahaan (CV. Padi Mas, selaku produsen beras Sikoki) dan studi kepustakaan.

\section{Hasil Penemuan dan Diskusi}

Setelah melakukan penelitian pada beras Sikoki, maka penulis mencoba memaparkan strategi komunikasi pemasaran beras Sikoki dalam memasarkan produk di beberapa wilayah Jakarta, khususnya Jakarta Barat. Kurang lebih selama tiga bulan mengacu pada beberapa elemen komunikasi pemasaran atau biasa disebut dengan Intergrated Marketing Communication (IMC), di mana secara garis besar pemasaran yang dilakukan oleh CV. Padi Mas (selaku produsen beras Sikoki) terbagi atas tiga bagian yaitu marketing communication, sales promotion, dan marketing event. Ketiga elemen pemasaran tersebut mempunyai strategi komunikasi pemasarannya masing-masing, diantaranya adalah periklanan, promosi penjualan, personal selling, direct and online marketing.

Setiap strategi pemasaran tersebut digunakan oleh CV. Padi Mas untuk menentukan pemilihan segmentasi, targeting dan positioning yang diharapkan. Beras Sikoki terbukti kualitasnya yang membuat usaha ini berbeda dengan usaha dibidang produksi beras lainnya di beberapa wilayah Jakarta. Di mana pihak owner beras Sikoki memasarkan secara menyeluruh. Oleh karena itu, maka perlu dibuat promosi dengan strategi jitu agar dapat menarik perhatian konsumen. Strategi komunikasi pemasaran yang bertujuan menentukan bentuk promosi yang akan diselenggarakan agar nantinya promosi tersebut bisa berjalan sesuai dengan apa yang diharapkan perusahaan.

Guna mengetahui beberapa hal terkait dengan komunikasi pemasaran, penulis melakukan wawancara (interview) dengan narasumber yang berkompeten, diantaranya adalah pemilik (owner) CV. Padi Mas (produsen beras Sikoki), penjual dan konsumen beras Sikoki.

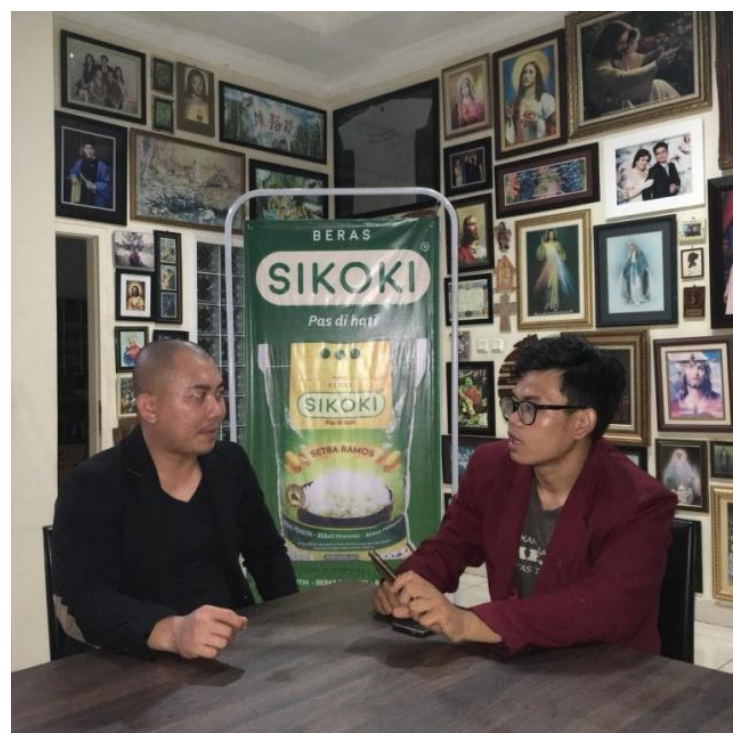

Gambar 1.Penulis Wawancara dengan Bapak Steven selaku owner CV. Padi Mas (produsen beras Sikoki) 
Penulis melakukan wawancara dengan Bapak Steven terkait dengan bagaimana cara memasarkan brand beras Sikoki kepada masyarakat. Adapun uraian penjelasannya adalah sebagai berikut :

Cara kami memasarkan ada bebeberapa cara, secara garis besar mungkin adalah offline dan online. Secara online adalah kita memasarkannya melalui instagram, e-commerce; tokopedia dan sebagainya dan kemudian melalui whatshap. Sedangkan, secara offline adalah kita bekerjasama dengan geraigerai yang bekerjasama dengan beras Sikoki.

Berdasarkan hasil wawancara di atas bersama owner beras Sikoki, Penulis dapat menyimpulkan bahwa strategi owner beras Sikoki adalah strategi komunikasi pemasaran yang terintegrasi melalui strategi pemilihan media yang hebat dan sangat berpengaruh besar terhadap kinerja penjualan produknya. Sang owner dalam hal ini juga mampu mengenali kekuatan persuasi tampilan visual di media sosual, menciptanya personanya untuk memahami pelanggannya sehingga mampu terhubung dengan berbagai bentuk kerjasama melalui media social, serta tidak kalah pentingnya adalah telah mengenal dan tahu betul akan konten unggulan yang digunakan di media sosial.

Saat penulis menanyakan kepada owner CV. Padi Mas (produsen beras Sikoki) mengenai sarana untuk memperkenalkan produk, Beliau mengatakan bahwa:

"Ketika kita memiliki sebuah usaha tentu memerlukan sarana untuk memperkenalkan produknya ke masyarakat, untuk itu strategi komunikasi pemasaran sangat membantu sebuah perusahaan dalam menentukan segmentasi, serta mencapai targeting dan positioning yang diharapkan."

Berdasarkan paparan dari owner, ia bahwa Beliau selalu menyusun strategi komunikasi dengan menentukan segmentasi konsumen dari produk yang ditawarkan, merencanakan target pemasaran serta gambaran produknya di pasaran. Selain itu, penting pula untuk melakukan pemilihan media yang hendak digunakan, sehingga proses komunikasi pemasaran kepada konsumen dapat berlangsung dengan baik.

Strategi komunikasi dapat dijalankan dengan baik apabila sasaran pembeli sudah ditentukan terlebih dahulu. Adapun pemilihan segmentasi konsumen beras Sikoki tidak terlepas dari target pemasarannya, yakni masyarakat yang berada di Jakarta umumnya dan wilayah Jakarta Barat pada khususnya. Hal ini berdasarkan hasil wawancara bersama Bapak Steven selaku owner CV. Padi Mas (produsen beras Sikoki) sebagai berikut:

"Dalam menjalankan strategi komunikasi pemasaran owner CV. Padi Mas memiliki segmentasi yaitu masyarakat umum, sedangkan targetnya adalah konsumen yang ada wilayah Jakarta pada umumnya dan Jakarta Barat pada khususnya."

Penggunaan IMC pada strategi komunikasi pemasaran beras Sikoki akan dibahas dalam tiga bagian tahapan yaitu:

\section{Marketing Communication}

Strategi komunikasi pemasaran yang digunakan sang owner beras Sikoki berbentuk pembinaan hubungan yang baik dengan masyarakat dan media dengan cara menciptakan pengembangan komunitas (community development). Walaupun efeknya lamban namun prosesnya bersifat berkelanjutan bagi perusahaan. Oleh karena itu, peran dari Marketing Communication ini sangat 
Evin Cornellin, Sinta Paramita: Komunikasi Pemasaran Brand Lokal Kepada Masyarakat Indonesia (Studi Terhadap Beras Sikoki)

penting. Seperti penjelasan Bapak Steven selaku owner CV. Padi Mas (produsen beras Sikoki) berikut ini:

"Marketing Communication sangat penting. Dapat dikatakan Marketing Communication mempunyai pekerjaan yang sangat kompleks. Dalam hal ini, Marketing Communication harus berpikir mengenai arah perusahaan hari demi hari, standar perusahaan yang diinginkan harus tertanam di benak pengunjung, meminimalisir konflik internal dan eksternal dan yang sangat penting Marketing Communication harus membuat kesan baik dan awareness (kesadaran) bagi konsumen”.

Berdasarkan wawancara tersebut, tersirat bahwa marketing communication adalah suatu hal yang memiliki peranan dalam setiap perusahaan dan sifatnya yang sangat kompleks mulai dari menyusun strategi pemasaran, memasang iklan, membangun kerja sama, dan mengangkat citra perusahaan. Sehingga pemilihan kegiatan dalam Marketing Communication sangat perlu untuk diperhatikan. Marketing Communication harus memiliki segudang ide kreatif dalam merencanakan strategi pemasaran.

Penulis juga menanyakan kepada Bapak Steven owner CV. Padi Mas (produsen beras Sikoki) terkait dengan kegiatan yang dilakukan oleh Marketing Communication, dan Beliau menjawab bahwa:

"Saat ini, kita telah melaksanakan berbagai strategi diantaranya program harga promo, bekerjasama dengan Alfamart, Indomaret, Tokopedia dan mengikuti beberapa event. Selain itu Marketing Communication juga selalu membuat press release untuk membentuk hubungan yang baik dengan media".

Ini artinya bahwa kegiatan-kegiatan yang dijalankan selalu mengacu pada strategi yang mengedepankan pada promo dengan bekerja sama Alfamart, Indomaret dan Tokopedia. Agar semua strategi dapat berjalan dengan baik dan sesuai yang diharapkan, Marketing Communication juga menjelaskan hal yang perlu diperhatikan dalam tahapan pelaksanaannya diantaranya sebelum pelaksanaan, kita harus menyiapkan terlebih dahulu media komunikasi yang akan digunakan.

\section{Sales Promotion}

Sales promotion atau biasa disebut promosi penjualan merupakan salah satu bagian Marketing yang owner CV. Padi Mas (produsen beras Sikoki), di mana promosi penjualan ini merupakan unsur penting dalam kegiatan promosi produk yang ditawarkan.

Penulis juga menanyakan kepada Bapak Steven perihal kegiatan promosi dalam kaitannya dengan tujuan menginformasikan, mempengaruhi dan membujuk, serta mengingatkan pelanggan sasaran tentang perusahaan. Sales promosi disini lebih mengarah kepada promosi di social network dan internet, di samping itu promosi penjualan ini dapat menarik pelanggan baru dan mendorong penggunaan produk. Beliau menjelaskan bahwa :

"Adapun cara promosi yang biasa dilakukan adalah melalui perbincangan dari seorang ke orang lain, referensi, komplaimen dari teman-keteman. Namun yang menjadi fokus utama sales promosi adalah media sosial dan 
internet dengan membangun networking ke perusahaan-perusahaan terkait dengan produk perusahaan."

Berdasarkan paparan tersebut terlihat bahwa social networking saat ini menjadi salah satu fokus utama owner beras Sikoki dalam memasarkan produknya. Hal ini dianggap cara yang paling cepat dalam menyampaikan pesan promosi ke Pelanggan dibanding media lainnya.

3. Marketing Event

Salah satu cara yang ampuh dalam menyampaikan pesan sebuah brand adalah dengan mengajak customer dan potential customer dalam event. Kegiatan pemasaran yang diselenggarakan harus memiliki pengaruh (impact) serta memberikan kesan mendalam kepada setiap orang yang hadir. Tujuannya agar customer maupun potential customer bisa cukup lama mengingat pengalaman yang menyenangkan tersebut. Strategi ini juga yang digunakan oleh owner beras Sikoki dalam menarik konsumen. Seperti yang dikatakan oleh Bapak Steven selaku owner CV. Padi Mas (produsen beras Sikoki) dalam hasil wawancara sebagai berikut :

"Event memiliki pengaruh yang besar karena keterlibatan pengunjung di dalamnya dan event memiliki peranan yang cukup besar dalam kegiatan komunikasi pemasaran.

Selain itu, dalam mengembangkan strategi komunikasi pemasaran yang efektif owner beras Sikoki juga memperhatikan bauran pemasaran yang terdiri dari 4P (Product, Price, Place, dan Promotion):

1. Product (produk)

Segala sesuatu yang ditawarkan kepada costumer untuk dilihat, dipegang, dibeli atau dikonsumsi.

2. Price (harga)

Sejumlah uang yang dibebankan untuk sebuah produk. Secara lebih luas, harga adalah keseluruhan nilai yang ditukarkan konsumen untuk mendapatkan keuntungan dari kepemilikan terhadap sebuah produk. Owner beras Sikoki selalu memberikan harga yang disesuaikan dengan target sasarannya.

3. Place (lokasi)

Keputusan penentuan lokasi dan saluran yang digunakan untuk memberikan produk kepada konsumen melibatkan pemikiran tentang bagaimana cara menentukan lokasi pertemuan dengan pelanggan yang tepat untuk menyampaikan produk ke pelanggan.

4. Promotion (promosi)

Kegiatan perusahaan dalam mempromosikan produknya yaitu dengan Memberitahukan informasi atau menawarkan produk melalui media iklan lini bawah (below the line) seperti kartu nama, spanduk dan brosur. Promosi ini dilakukan juga pada pemasaran langsung dengan memanfaatkan social networking seperti penggunaan jaringan internet, situs pertemanan seperti facebook, twitter, instagram dan media sosial lainnya, hal ini disesuaikan dengan kemajuan teknologi seperti internet yang berkembang saat ini.

Di sisi lain, penulis juga melakukan wawancara dengan penjual beras Sikoki di Pasar Meruya, Jakarta Barat yaitu dengan Bapak Widagdo Sutiman 
Evin Cornellin, Sinta Paramita: Komunikasi Pemasaran Brand Lokal Kepada Masyarakat Indonesia (Studi Terhadap Beras Sikoki)

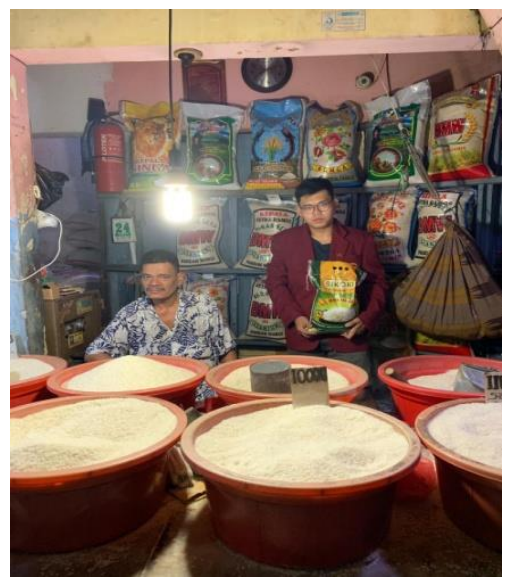

Gambar 2 Penulis bersama dengan Bapak Widagdo Sutiman selaku penjual beras Sikoki

Penulis melakukan wawancara dengan Bapak Widagdo Sutiman terkait dengan bagaimana cara memasarkan brand beras Sikoki kepada masyarakat. Adapun uraian penjelasannya adalah sebagai berikut :

"saya memasarkan beras Sikoki ini ke konsumen secara langsung, pembeli datang ke kios saya dan ada juga yang juga pesan melalui telepon, dan biasaya itu adalah konsumen atau langganan saya, dan anak buah saya yang mengantarnya ke tempat tujuan.

Ini artinya penjualan memasarkan produknya ke konsumen secara langsung dan juga melalui telepon. Ini adalah hal yang lazim dilakukan oleh beberapa pedagang di pasar atau di pinggir jalan.

Penulis bertanya kepada penjual mengenai strategi bisnis yang dijalankan, Beliau memberi penjelasan:

"Dalam menjalankan suatu usaha tentunya ada strategi bisnis. Ada beberapa hal yang perlu diperhatikan, diantaranya adalah (1) Memberi diskon untuk pelanggan yang membeli dalam jumlah banyak, (2) Memberikan jasa antar gratis untuk wilayah yang masih terjangkau, (3) Membuat brosur yang berisi jenis-jenis beras yang anda jual berdasarkan harganya dan tak terkalah penting adalah (4) menyediakan stok beras lebih untuk jenis yang paling banyak diminati."

Ini artinya bahwa dalam menjalankan bisnis harus memiliki strategi bisnis yang jitu guna menghadapi pesaing (competitor) sejenis, dan tak terkalah penting adalah memiliki jiwa kewirausahaan (entrepreneurship), mandiri, ulet, tahan banting dan mampu mengambil resiko.

Penulis dalam penulisan skripsi ini juga melakukan wawancara dengan pembeli beras Sikoki di Pasar Meruya, yaitu dengan Sdr. Herman Rusady. Dalam hal ini penulis banyak bertanya terkait dengan alasan apa, Sdr. Memilih membeli beras Sikoki ini? Dan Beliau memberi penjelasan bahwa :

"Selama 1 (satu) tahun ini saya membeli beras dengan brand Sikoki, alasannya adalah berasnya putih, pulen, bersih dan tanpa bahan pengawet, dan ini beras ini cocok untuk bahan olahan masakan orang tua saya yang membuka warung makan. Dan banyak pelanggan ibu saya yang puas dengan nasi yang dihidangkan di warung ibu saya." 
Ini berarti ada hubungan yang baik antara konsumen dan produk yang ditawarkan, dalam hal ini beras dengan brand Sikoki. Konsumen merasa terpuaskan dengan rasa beras yang pulen dan enak rasanya.

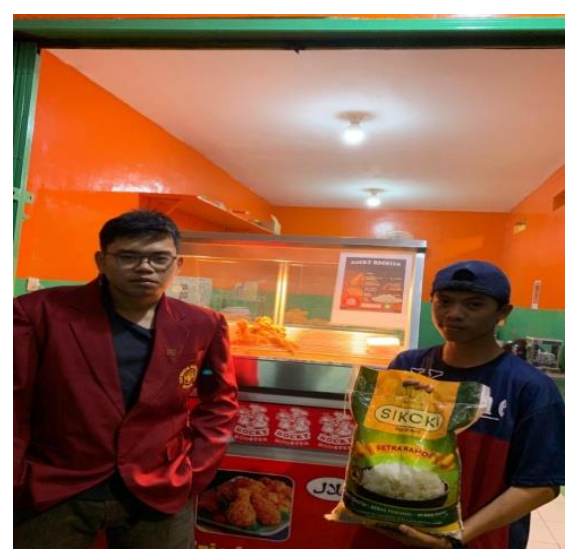

Gambar 3Penulis Wawancara dengan Sdr. Herman Rusady selaku konsumen atau pembeli beras Sikoki

Penulis juga bertanya kepada Sdr. Herman Rusady selaku konsumen beras Sikoki, terkait dengan kelebihan Beras Sikoki, beliau memberi penjelasan bahwa :

"Selain saya membantu orangtua membuka warung makan, saya juga menjual ayam gorong dengan menggunakan tepung beras. Dan tepung ayam ini dibuat sendiri dengan bahan dari beras Sikoki". Terkait dengan kelebihan beras Sikoki adalah banyak sekali, selain putih, bersih dan tanpa bahan pengawet, beras Sikoki ini cocok untuk ayam goreng dengan menggunakan bahan tepung beras dari beras Sikoki, dan ini juga banyak testimoni dari langganan saya".

Ini artinya bahwa Beras Sikoki bisa digunakan untuk bahan olahan masakan lainnya, tak terkecuali untuk nasi box ayam goreng, ayam goreng tepung beras, ayam krispy tepung beras dan kue-kue lainnya. Dan ini adalah kelebihan dari brand beras Sikoki.

Pada pertanyaan lain, peneliti juga mempertanyakan mengenai mengapa anda memilih beras Sikoki?

"Pada dasarnya saya memilih beras brand Sikoki ini, selain berasnya putih, juga karena beras ini pulen, gurih dan tentunya tidak menggunakan bahan / zat kimia atau zat pemutih. "

Ini artinya bahwa beras yang putih, pulen dan tidak menggunakan bahan pemutih atau bahkan bahan pengawet menjadi pilihan bagi konsumen rumahan atau bahkan konsumen yang menggunakannya untuk berjual seperti warung, dan lain-lain.

Pada pertanyaan berikutnya, adalah apakah anda sering berkomunikasi dengan pedagang beras Sikoki pada saat membeli produk brand beras Sikoki tersebut?

"Tidak sering juga, karena saya kalau berkomunikasi juga pada saat melakukan pemesanan atau bahkan datang ke toko penjual beras Sikoki, dan bahkan saya sering diberi kemurahan atau diskon atau bahkan dilebihi beras dan dimasukkan ke keranjang dagang ketika ke pasar". 
Evin Cornellin, Sinta Paramita: Komunikasi Pemasaran Brand Lokal Kepada Masyarakat Indonesia (Studi Terhadap Beras Sikoki)

Hal tak terkalah penting bahwa seluruh cara CV. Padi Mas menarik perhatian konsumen. Menarik perhatian konsumen dalam membentuk sikap terhadap produk, membentuk sebuah persepsi terhadap produk, dan membentuk keputusan konsumen untuk membeli produk, serta membuat konsumen untuk merekomendasikan produk kepada orang lain.

Hal tak terkalah penting, bahwa komunikasi pemasaran memegang kendali dalam penjualan produk, jika komunikasi tersebut mengalami kendala maka penjualan bisa terhenti sesaat atau bahkan berhenti total. Dalam komunikasi ini sarana yang digunakan sangat beragam dalam menginformasikan setiap produk yang dipasarkan. Komunikasi pemasaran mampu berbentuk suatu ekuitas merk juga penjualan produk, lingkungan pemasaran yang dapat mengubah sangat cepat komunikasi guna mendorong suatu penjualan, namun dengan melalui banyak komunikasi pemasaran melalui sebuah iklan, bukanlah satu-satunya yang yang dapat mendorong penjualan. Namun melalui buaran komunikasi yang dilakukan dengan terintegrasi hal tersebut mampu meningkatkan penjualan perusahaan, bukan hanya itu saja, dengan semakin luasnya komunikasi secara publik atau pribadi akan dapat menjangkau pasar yang lebih luas yang akan mendorong efektifitas dan efisiensi dalam melakukan komunikasi pemasaran.

Strategi dalam membentuk sebuah komunikasi dalam pemasaran dengan strategi promosi produk, khususnya brand beras Sikoki, hal yang paling penting guna mendorong suksesnya kegiatan pemasaran adalah dengan beberapa strategi guna menjalin komunikasi pemasaran dalam hubungannya dengan pemasaran beras Sikoki, diantaranya dengan bauran promosi yang meliputi promosi penjualan, pemasaran langsung, promosi iklan dan internet marketing.

Di sisi lain, penulis juga menggaris bawahi bahwa ada beberapa cara dalam melakukan komunikasi pemasaran yang bisa anda coba sebagai sarana efektif mendapatkan banyak pelanggan. Sarana dalam komunikasi pemasaran di antaranya:

\section{Face to Face}

Komunikasi pemasaran satu ini merupakan komunikasi secara langsung yang dilakukan penjual kepada pembeli. Bila anda menjalankan komunikasi ini maka sering terjadi kendala pada waktu dan biaya sehingga komunikasi langsung ini kadang tidak diminati para marketer bisnis

2. Internet

Internet merupakan sarana komunikasi pemasaran yang hebat dan hampir semua pebisnis menjalankan pemasarannya melalui internet. Internet lebih mudah menginformasikan produk dan internet memiliki jumlah pengguna yang banyak.

Komunikasi pemasaran brand lokal khususnya Beras Sikoki adalah menggunakan konsep strategi komunikasi terintegrasi. Hal ini ditandai dengan terlihatnya strategi bauran promosi dan strategi pemilihan media yang tepat dan efektif menggunakan media sosial. Adapun bentuk strategi komunikasi pemasaran yaitu:

a. Melakukan promosi di berbagai jejaring sosial.

b. Melakukan aktivitas iklan seperti membuat testimoni

c. Menjalin kerjasama dengan Reseller di beberapa Jakarta, khususnya Jakarta Barat.

d. Melakukan personal selling kepada konsumen.

e. Merespon segala bentuk pertanyaan dan memberikan umpan balik kepada konsumen yang ingin berkomunikasi kepada agen. 
f. Memberikan fasilitas dan pelayanan yang ramah kepada konsumen secara langsung.

Dengan begitu, image (citra) beras Sikoki akan terus terjaga. Di mana image dibentuk melalui proses stimuli yang ditangkap oleh indra (persepsi) dan lalu ditafsirkan sendiri oleh penerima stimuli tersebut dengan memberi arti melaui asosiasi berdasarkan pengetahuan yang dimiliki sebelumnya. Sebuah citra juga menjadi sarana bagi CV. Padi Mas (produsen beras Sikoki) untuk mengumpulkan informasi penting yang menyangkut produk atau perusahaan dari publiknya, sehingga dengan informasi yang diperoleh tersebut dapat dijadikan bahan masukan untuk mengukur dan mengambil kebijakan yang tepat bagi penjualan yang tepat bagi penjualan.

Pada dasarnya, strategi pemasaran yang banyak digunakan oleh CV. Padi Mas (produsen beras Sikoki) ini adalah model pemasaran digital dengan menggunakan media sosial, seperti instagram, facebook, whatshap dan juga Tokopedia dan lainlain.

\section{Simpulan}

Kesimpulan dari penelitian yang dilakukan adalah sebelum memulai pelaksanaan strategi komunikasi pemasaran beras Sikoki, perusahaan melewati tahap-tahap perencanaan strategi komunikasi pemasaran yaitu, menentukan segmentasi, target pasar, positioning dan diferensiasi. Hal ini dimaksudkan agar dalam mempromosikan produknya dapat dilaksanakan secara efektif dan efisien. Dalam melaksanakan strategi komunikasi pemasaran, perusahaan juga menggunakan bauran promosi yang meliputi promosi penjualan, pemasaran langsung, promosi iklan dan internet marketing. Terkait dengan promosi iklan yaitu melalui posting produk di media sosial yaitu facebook dan instagram. Internet marketing menggunakan media sosial facebook dan instagram, aplikasi pesan dan sistem reseller. Dalam bauran promosi yang telah dilakukan perusahaan dapat diketahui bahwa banyak kegiatan promosi yang dilakukan dengan menggunakan media online. Dua jenis saluran media online yang paling banyak digunakan adalah instant messaging dan media sosial: facebook dan instagram. Kedua media online tersebut saling berkaitan dan sangat berdampak terhadap keberhasilan promosi dan penjualan produk yang dilakukan perusahaan terkait dengan produk beras Sikoki.

\section{Ucapan Terima Kasih}

Penulis mengucapkan terima kasih kepada seluruh narasumber, yaitu Bapak Steven selaku owner CV. Padi Mas (produsen beras Sikoki), Bapak Widagdo Sutiman selaku penjual beras Sikoki dan Sdr. Herman Rusady selaku konsumen atau pembeli beras Sikoki yang berdomisili di Jakarta Barat, yang telah bersedia bekerja sama dan memberikan waktu dalam proses pengumpulan data penelitian ini. kemudian ucapan terima kasih juga diberikan kepada Dosen Fakultas Ilmu Komunikasi Universitas Tarumanagara yang telah memberikan bimbingan dan arahan atas terselesaikannya penelitian ini. Terakhir kepada seluruh rekan-rekan diskusi di Fakultas Ilmu Komunikasi Universitas Tarumanagara. 
Evin Cornellin, Sinta Paramita: Komunikasi Pemasaran Brand Lokal Kepada Masyarakat Indonesia (Studi Terhadap Beras Sikoki)

\section{Daftar Pustaka}

Alifahmi, Hifni, (2005). Strategi Komunikasi Pemasaran: Integrasi Iklan, Public. Relations, dan Promosi. Bandung: PT.Mizan Pustaka.

Cangara, Hafied. (2005). Pengantar Ilmu Komunikasi. Jakarta: Kencana Prenada.

Cravens, David W dan Piercy, Nigel F. (2013). Marketing Management: Strategic Planning; Marketing Management, Case Studies. New York. McGraw-Hill.

Fill. C.(2009). Marketing Communications: Contexts, Contents, and Strategies. Herthfordshire: Prentice Halls.

Keller, Lane Kevin. (2003). Strategic Brand Management: Building, Measuring, And Managing Brand Equity. (Second Edition). New Jersey: Prentice Hall.

Keller, Lane Kevin. (2003). Strategic Brand Management : Building, Measuring, And Managing Brand Equity. (Fifth Edition). New Jersey: Prentice Hall.

Khoo Kheng Hor, (2005). Marketing Wise. Jakarta: Gramedia Pustaka.

Kotler, Philip dan Gary Armstrong. (2008). Prinsip-Prinsip Pemasaran. Edisi 12. Jilid 1. Jakarta: Erlangga.

Priansa, Donni Juni. (2017). Komunikasi Pemasaran Terpadu. Bandung: CV. Pustaka Setia.

Ruslan, R. (2010). Manajemen dan Public Relations dan Media Komunikasi. Jakarta: Raja Grafindo Persada.

Scott Stratten \& Alison Stratten, (2019). UNBranding: 100 Pelajaran Branding di Era Disruptif, Jakarta: PT. Gramedia.

Tjiptono, Fandy. (2001). Strategi Pemasaran. Yogyakarta: ANDI.

Tjiptono, Fandy. (2005). Brand Managment \& Strategy. Yogyakarta: Andi.

William G. Nickels, (2004). Marketing Communication and Promotion. New York: McGraw-Hill Education. 